\title{
KAJIAN KOMUNITAS EKOSISTEM LAMUN DI SEMENANJUNG TARABITAN KECAMATAN LIKUPANG BARAT KABUPATEN MINAHASA UTARA
}

\author{
(Study of Seagrass Communities in The Tarabitan Peninsula West Likupang \\ North Minahasa Regency)
}

\author{
Risandi D. Sitaba, Carolus P. Paruntu, Billy Th. Wagey* \\ Program Studi IImu Kelautan, Fakultas Perikanan dan IImu Kelautan Universitas Sam \\ Ratulangi, Manado.
}

*corresponding author: billywagey@unsrat.ac.id

\begin{abstract}
This research was conducted in the waters of Tarabitan Peninsula, West Likupang North Minahasa using quadants transect method. The purpose of this study was to determine the community structure of seagrass found in that waters as initial information for sustainable management seagrass ecosystem . Field observation was conducted to identify the seagrass species, number of individuals/shoots, percent cover for each type of seagrass in those plotting quadrants. The result of this study documented 6 types of seagrass namely, Enhalus acoroides, Thalassia hemprichii, Cymodocea rotundata, Syringodium isoetifolium, Halophila ovalis and Halodule uninervis. The species composition and distribution of seagrass were varied and was dominated by Thalassia hemprichii was the most dominant seagrass species with a relative density of $55.55 \%$, a relative frequency of $33.67 \%, 39.92 \%$ relative cover, an important value index of $129.03 \%$, a diversity index of 1.30 belonging to this condition, moderate, the uniformity index of 0.72 is classified as high and the dominance index of 0.2 is classified as low. Based on Minister of Environment Decree Republic Indonesia No. 200 of 2004 concerning the status of seagrass beds, the condition of the seagrass beds in the waters of Tarabitan Village is classified as rich / healthy with a cover value of $\geq 60$.
\end{abstract}

Keywords : Seagrass Community, Species Composition, distribution, Tarabitan Peninsula

Penelitian ini dilakukan di perairan Semenanjung Tarabitan Likupang Barat Minahasa Utara dengan menggunakan metode transek kuadran. Tujuan penelitian ini adalah untuk mengetahui struktur komunitas lamun yang terdapat di perairan tersebut sebagai informasi awal untuk pengelolaan lamun secara berkelanjutan. Pengamatan lapangan dilakukan untuk mengidentifikasi jenis lamun, jumlah individu/tegakan, persentase tutupan tiap jenis lamun pada tiap kuadran. Hasil penelitian ini mendokumentasikan 6 jenis lamun yaitu Enhalus acoroides, Thalassia hemprichii, Cymodocea rotundata, Syringodium isoetifolium, Halophila ovalis dan Halodule uninervis. Komposisi jenis dan sebaran lamun bervariasi dan didominasi oleh jenis lamun Thalassia hemprichii merupakan jenis lamun yang paling dominan dengan kerapatan relatif $55,55 \%$, frekuensi relatif $33,67 \%$, tutupan relatif $39,92 \%$, indeks nilai penting $129,03 \%$, indeks keanekaragaman 1,30 tergolong dalam kondisi sedang, indeks keseragaman 0,72 tergolong tinggi dan indeks dominansi 0,2 tergolong rendah. Berdasarkan Keputusan Menteri Lingkungan Hidup Nomor 200 Tahun 2004, kondisi padang lamun di perairan Desa Tarabitan tergolong kaya / sehat dengan nilai tutupan $\geq 60$.

Kata Kunci: Komunitas Lamun, Komposisi Jenis, Distribusi, Semenanjung Tarabitan 


\section{PENDAHULUAN}

Lamun merupakan tumbuhan berbunga (angiospermae) yang mampu tumbuh dan berkembang dengan baik di perairan dangkal (Wood dkk., 1986 dalam Tangke, 2010). Semua jenis lamun merupakan tumbuhan berbiji satu (monokotil) serta memiliki akar, rimpang (rhizoma), daun bunga dan buah, sama halnya dengan tumbuhan yang tumbuh di daratan. Di perairan dangkal lamun dapat ditemui tumbuh membentuk hamparan padang serta mirip seperti tumbuhan ilalang di daratan yang dapat terdiri dari satu species (monospesific) dan beberapa spesies (multispesific) olehnya disebut padang lamun (Wagey, 2013).

Padang lamun memegang peranan penting pada lingkungan perairan, terkait fungsinya sebagai stabilisasi serta penahan sedimen, mengembangkan sedimen, meredam pergerakan gelombang, daerah feeding, nursery, dan spawning ground, juga sebagai tempat terjadinya sirkulasi sediment (Sakaruddin, 2011).

Menurut Sheppard dkk (1996) dalam Tangke (2010), ekosistem padang lamun yang tumbuh sebagai vegetasi dominan diperairan mampu tumbuh secara permanen diperairan tersebut. Keberadaan ekosistem padang lamun diperairan sangat kompleks serta memiliki peran dan manfaat signifikan diperairan baik secara biologi maupun ekologi.

Umumnya ekosistem padang lamun dapat dijumpai di daerah pesisir pada kedalaman 5 meter saat air pasang, namun beberapa jenis lamun dapat tumbuh hingga mencapai kedalaman 90 meter di dasar laut, selama kondisi lingkungannya dapat menunjang. Ekosistem padang lamun di Indonesia biasanya berada diantara ekosistem mangrove dan terumbu karang, atau berada di dekat pantai berpasir dan hutan pantai (Rahmawati, dkk. 2014 dalam Hartini \& Lestarini, 2019).

Terdapat 60 spesies lamun di dunia, dari jumlah keseluruhan 20 jenis dapat dijumpai di Asia Tenggara, dari 20 spesies tersebut bisa ditemui diperairan Indonesia yaitu terdiri dari 12 spesies, yang penyebarannya hampir diseluruh perairan Indonesia dari sabang hingga merauke, terkhusus daerah pesisir yang memiliki kontur landai serta bersubstrat agak berpasir dan berlumpur (Sakaruddin, 2011).

\section{Tujuan Penelitian}

Tujuan penelitian ini yaitu, mengkaji nilai komunitas lamun (kerapatan jenis, kerapatang relatif, frekuensi jenis, frekuensi relatif, penutupan jenis, penutupan relatif, indeks nilai penting, indeks keanekaragaman, indeks keseragaman dan indeks dominansi) di Semenanjung Tarabitan.

\section{METODE PENELITIAN}

\section{Tempat dan Waktu Penelitian}

Penelitian ini dilaksanakan di Desa Tarabitan, Kecamatan Likupang Barat, Kabupaten Minahasa Utara, pada tanggal 6 Oktober 2020 s/d 29 Desember 2020.

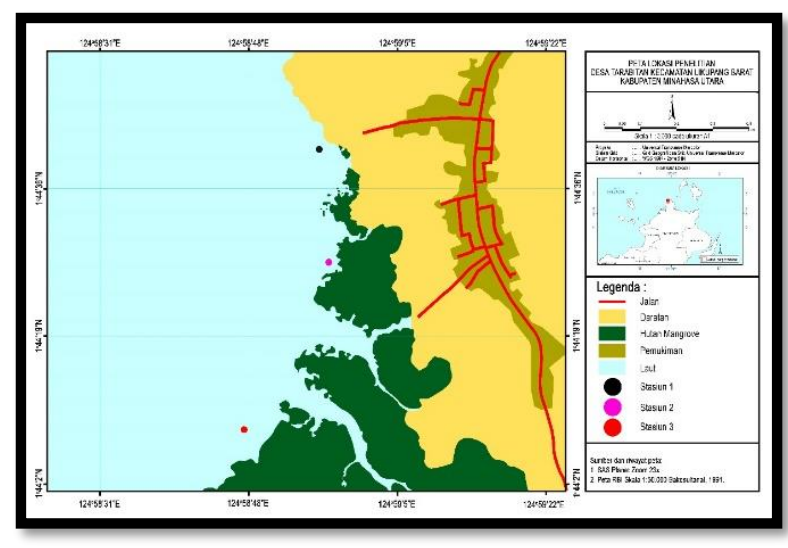

Gambar 1. Peta Lokasi Penelitian

\section{Alat dan Bahan}

Kegiatan penelitian ini menggunakan beberapa peralatan, untuk menunjang aktivitas pengambilan data di lapangan, yang disajikan dalam Tabel 1 berikut:

Tabel 1. Alat dan Bahan Penelitian 


\begin{tabular}{|c|c|c|}
\hline No & $\begin{array}{l}\text { Nama } \\
\text { Alat/Bahan }\end{array}$ & Kegunaan \\
\hline 1. & $\begin{array}{l}\text { Kuadran } 50 x \\
50 \mathrm{~cm}\end{array}$ & $\begin{array}{l}\text { Sebagai media untuk } \\
\text { menghitung luasan } \\
\text { tutupan lamun }\end{array}$ \\
\hline 2 & $\begin{array}{l}\text { Roll meter } 50 \\
\mathrm{~m}\end{array}$ & $\begin{array}{l}\text { Sebagai patokan untuk } \\
\text { peletakan kuadran (line } \\
\text { transect) }\end{array}$ \\
\hline 3 & $\begin{array}{l}\text { Underwater } \\
\text { camera }\end{array}$ & $\begin{array}{l}\text { Untuk } \\
\text { mendokumentasikan } \\
\text { proses pengambilan } \\
\text { data }\end{array}$ \\
\hline 4 & $\begin{array}{l}\text { Meter } \\
\text { kain/mistar }\end{array}$ & $\begin{array}{l}\text { Untuk mengukur tinggi } \\
\text { kanopi }\end{array}$ \\
\hline 5 & $\begin{array}{l}\text { Papan } \\
\text { sabak/kertas } \\
\text { tahan Air }\end{array}$ & $\begin{array}{l}\text { Untuk mencatat hal-hal } \\
\text { penting, terkait } \\
\text { pengambilan data di } \\
\text { lokasi penelitian seperti } \\
\text { waktu, tutupan } \\
\text { lamundan, jenis lamun } \\
\text { dll. }\end{array}$ \\
\hline 6 & Perahu & $\begin{array}{l}\text { Transportasi ke lokasi } \\
\text { pengambilan data serta } \\
\text { untuk mengangkut } \\
\text { beberapa peralatan } \\
\text { lapangan. }\end{array}$ \\
\hline 7 & Boots & $\begin{array}{l}\text { Pelindung kaki selama } \\
\text { beraktivitas di daerah } \\
\text { lamun }\end{array}$ \\
\hline 8 & GPS & $\begin{array}{l}\text { Menandai lokasi } \\
\text { pengambilan data }\end{array}$ \\
\hline 9 & $\begin{array}{l}\text { Peralatan } \\
\text { snorkeling }\end{array}$ & $\begin{array}{l}\text { Memudahkan proses } \\
\text { pengambilan data di } \\
\text { dalam air }\end{array}$ \\
\hline 10 & Lamun & $\begin{array}{l}\text { Sebagai bahan yang } \\
\text { akan diamati }\end{array}$ \\
\hline 11 & $\begin{array}{l}\text { Panduan } \\
\text { identifikasi } \\
\text { lamun } \\
\text { (SeagrassWatch) }\end{array}$ & $\begin{array}{l}\text { Untuk panduan dalam } \\
\text { identifikasi lamun }\end{array}$ \\
\hline 12 & $\begin{array}{l}\text { Standar } \\
\text { prosentase } \\
\text { tutupan lamun } \\
\text { (SeagrassWatch) }\end{array}$ & $\begin{array}{l}\text { Untuk panduan dalam } \\
\text { memperkirakan } \\
\text { persentase tutupan } \\
\text { lamun }\end{array}$ \\
\hline
\end{tabular}

\section{Penentuan Stasiun Pengamatan}

Penentuan stasiun pengamatan ditentukan dengan melakukan survei terlebih dahulu ke lokasi yang direncanakan untuk melihat keberadaan padang lamun. Stasiun pengamatan terdiri dari tiga titik dan pada setiap titik pengamatan terdapat 3 line transect pengambilan data yang dianggap dapat mewakili kawasan ekosistem padang lamun yang berada di area tersebut.

\section{Metode Pengambilan Data}

Metode penelitian dilakukan secara purposive sampling dengan harapan metode ini dapat mewakili lokasi pengamatan, berdasarkan keberadaan struktur komunitas lamun. Pengambilan data lamun menggunakan metode line transect yang diadopsi oleh SeagrassWatch (telah dimodifikasi). Line transect ditarik tegak lurus dari garis pantai ke arah laut sejauh 50 meter, selanjutnya pengamatan dilakukan menggunakan kuadran dengan ukuran 50 x 50 $\mathrm{cm}^{2}$ yang diletakkan secara sistematis di sepanjang garis transek dengan jarak antar kuadran 5 m. Kusumaningtyas dkk (2015). Dalam satu titik atau stasiun pengamatan menggunakan 3 line transect dengan jarak antar transek $50 \mathrm{~m}$. Untuk mengetahui/mengidentifikasi jenis-jenis lamun menggunakan panduan dari SeagrassWatch.

\section{Pengolahan dan Analisis Data}

Data ekosistem padang lamun diolah menggunakan perangkat lunak Microsoft Exel 2016. Dalam proses pengolahan data terdiri dari beberapa tahapan yang nantinya akan menghasilkan nilai rata-rata penutupan lamun (\%) dan persentase tutupan lamun per jenis, termasuk komposisinya, dalam suatu area pengamatan (Rahmawati dkk., 2014). Adapun tahapan pengolahan datanya mengacu pada (Septian, Azizah dan Apriadi, 2016) sebagai berikut:

\section{Kerapatan Jenis}

Kerapatan jenis merupakan perbandingan antara jumlah total individu dengan unit area yang diukur. Kerapatan jenis lamun dapat dihitung dengan persamaan (Tuwo, 2011 dalam Septian, Azizah dan Apriadi, 2016):

$$
\mathrm{KJi}=\frac{\mathrm{Ni}}{\mathrm{A}}
$$

Keterangan

$\underset{\left(\text { tegakan } / \mathrm{m}^{2}\right)}{\mathrm{KJi}}=$ Kerapatan jenis keke-i (tegakan)

$\mathrm{Ni}=$ Jumlah total individu dari jenis sampel $\left(\mathrm{m}^{2}\right)$

$\mathrm{A}=$ Luas area total pengambilan

\section{Kerapatan Relatif}

Kerapatan relatif merupakan perbandingan antara jumlah individu jenis dan jumlah total individu seluruh jenis. Kerapatan 
relatif lamun dapat dihitung dengan persamaan (Tuwo, 2011 dalam Septian, Azizah dan Apriadi, 2016):

$$
\mathrm{KR}=\frac{\mathrm{Ni} \times 100}{\Sigma \mathrm{n}}
$$

Keterangan:

(ind $/ \mathrm{m}^{2}$ )

$$
\begin{array}{ll}
\mathrm{KR} & =\text { Kerapatan relatif }(\%) \\
\mathrm{Ni} & =\text { Jumlah individu jenis ke-i }
\end{array}
$$
(ind $/ \mathrm{m}^{2}$ )

$\sum \mathrm{n} \quad=$ Jumlah individu seluruh jenis

Berdasarkan persamaan di atas, kerapatan lamun dikategorikan dengan nilainilai sebagai berikut:

Tabel 2. Skala Kondisi Padang Lamun Berdasarkan Tingkat Kerapatan. (Haris dan Gosari, 2012 dalam Martha, Julyantoro dan Sari, 2018).

\begin{tabular}{|c|c|c|}
\hline Skala & Kerapatan $\left(\mathrm{ind} / \mathrm{m}^{2}\right)$ & Kondisi \\
\hline 5 & $>175$ & $\begin{array}{c}\text { Sangat } \\
\text { rapat }\end{array}$ \\
\hline 4 & $125-175$ & Rapat \\
\hline 3 & $75-25$ & Agak rapat \\
\hline 2 & $25-75$ & Jarang \\
\hline 1 & $<25$ & $\begin{array}{c}\text { Sangat } \\
\text { Jarang }\end{array}$ \\
\hline
\end{tabular}

\section{Frekuensi Jenis}

Frekuensi jenis merupakan perbandingan antara jumlah petak sampel yang ditemukan suatu jenis lamun dengan jumlah total petak sampel yang diamati. Frekuensi jenis lamun dapat dihitung dengan persamaan (Tuwo, 2011 dalam Septian, Azizah dan Apriadi, 2016):

$$
\begin{aligned}
\mathrm{FJi}=\frac{\mathrm{Pi}}{\Sigma \mathrm{P}} & \\
\text { Keterangan } & \\
\mathrm{Fji} & =\text { Frekuensi jenis ke-i } \\
\mathrm{Pi} & =\text { Jumlah petak sampel tempat }
\end{aligned}
$$
ditemukan jenis ke-i yang diamati

$$
\Sigma \mathrm{P}=\text { Jumlah total petak sampel }
$$

\section{Frekuensi Relatif}

Frekuensi relatif merupakan perbandingan antara frekuensi jenis ke-i dengan jumlah frekuensi untuk seluruh jenis. Frekuensi relatif lamun dapat dihitung dengan persamaan (Tuwo, 2011 dalam Septian, Azizah dan Apriadi, 2016):

$$
\mathrm{FR}=\frac{\mathrm{Fi}}{\Sigma \mathrm{F}}
$$

Keterangan

$\mathrm{FR}=$ Frekuensi relatif $(\%)$

$\mathrm{Fi} \quad=$ Frekuensi jenis ke-i

$\Sigma \mathrm{F}=$ Jumlah frekuensi untuk

seluruh jenis

\section{Penutupan Jenis}

Penutupan jenis merupakan perbandingan antara luas area yang ditutupi oleh jenis lamun ke-i dengan jumlah total area yang ditutupi lamun. Penutupan jenis lamun dapat dihitung dengan persamaan (Tuwo, 2011 dalam Septian, Azizah dan Apriadi, 2016):

$$
\mathrm{PJ}=\frac{\mathrm{ai}}{\mathrm{A}}
$$

Keterangan

i (\%)

$$
\text { PJ = Penutupan jenis ke-i }\left(\% / \mathrm{m}^{2}\right)
$$

ai = Luas total penutupan jenis ke-

\section{ditutupi lamun $\left(\mathrm{m}^{2}\right)$}

$A=$ Jumlah total area yang

\section{Penutupan Relatif}

Penutupan Relatif (PR) yaitu perbandingan antara penutupan individu jenis ke-i dan total penutupan seluruh jenis. Penutupan relative lamun dapat dihitung dengan persamaan (Tuwo, 2011 dalam Septian, Azizah dan Apriadi, 2016):

$$
\mathrm{PR}=\frac{\mathrm{Pi}}{\mathrm{P}}
$$

Keterangan:

$$
\begin{array}{ll}
\mathrm{PR} & =\text { Penutupan relatif }\left(\% / \mathrm{m}^{2}\right) \\
\mathrm{Pi} & =\text { Penutupan jeni ke-i }\left(\% / \mathrm{m}^{2}\right) \\
\mathrm{P} & =\text { Penutupan seluruh jenis }
\end{array}
$$
lamun $\left(\% / \mathrm{m}^{2}\right)$

Data dari hasil perhitungan tutupan lamun diketahui untuk menentukan status padang lamun berdasarkan Kepmen LH No. 200 tahun 2004, sebagi berikut. (Martha, Julyantoro dan Sari, 2018).

Tabel 3. Status Padang Lamun

\begin{tabular}{|l|l|l|}
\hline \multicolumn{2}{|c|}{ Kondisi } & \multicolumn{1}{c|}{$\begin{array}{c}\text { Penutupan } \\
(\%)\end{array}$} \\
\hline Baik & Kaya/sehat & $\geq 60$ \\
\hline \multirow{2}{*}{ Rusak } & $\begin{array}{l}\text { Kurang kaya/kurang } \\
\text { sehat }\end{array}$ & $30-59,9$ \\
\cline { 2 - 3 } & Miskin & $\leq 29,9$ \\
\hline
\end{tabular}




\section{Indeks Nilai Penting}

Indeks nilai penting digunakan untuk menghitung keseluruhan dari peranan jenis lamun di dalam satu komunitas. Rumus yang digunakan untuk menghitung indeks nilai penting adalah (Kordi, 2011 dalam Septian, Azizah dan Apriadi, 2016):

$$
\mathrm{INP}=\mathrm{FR}+\mathrm{KR}+\mathrm{PR}
$$

Keterangan

$$
\begin{array}{ll}
\text { INP } & =\text { Indeks nilai penting } \\
\text { FR } & =\text { Frekuensi relatif } \\
\text { KR } & =\text { Kerapatan relatif } \\
\text { PR } & =\text { Penutupan relatif }
\end{array}
$$

\section{Indeks Keanekaragaman}

Keanekaragaman jenis lamun dihitung menggunakan indeks keanekaragaman Shannon-Weaner (Odum, 1996 dalam Septian, Azizah dan Apriadi, 2016):

$$
H^{\prime}=\sum_{t=1}^{S} \text { pi ln pi }
$$

$$
\mathrm{H}^{\prime}=-\Sigma(\mathrm{ni} / \mathrm{N} \ln \mathrm{ni} / \mathrm{N})
$$

\section{Keterangan :}

$$
\mathrm{H}^{\prime} \quad=\text { Indeks keanekaragaman }
$$

Shannon-Wienner

$$
\begin{array}{ll}
\mathrm{pi} & =\text { ni/N } \\
\mathrm{ni} & =\text { Jumlah induvidu jenis ke-i } \\
\mathrm{N} & =\text { Jumlah total induvidu } \\
\mathrm{S} & =\text { Jumlah spesies }
\end{array}
$$

Dengan nilai :

$\mathrm{H}^{\prime}>3$ keanekaragaman spesies tinggi sedang

$$
1 \leq H^{\prime} \leq 3 \text { keanekaragaman spesies }
$$

rendah

$$
H^{\prime}<1 \text { keanekaragaman spesies }
$$

\section{Indeks Keseragaman}

Indeks keseragaman lamun dapat dihitung dengan rumus (Odum, 1996 dalam Septian, Azizah dan Apriadi, 2016):

Keterangan :

$$
e=\mathrm{H}^{\prime} / \mathrm{Hmax}
$$

$$
\begin{array}{ll}
\mathrm{e} & =\text { Indeks keseragaman } \\
\mathrm{H}^{\prime} & =\text { Indeks Keanekaragaman } \\
\mathrm{H} \max & =\log 2(\mathrm{~S}) \\
\mathrm{S} & =\text { Jumlah spesies }
\end{array}
$$

Nilai indeks keseragaman berkisar antara 0 1 , dengan kategori,

$$
\begin{aligned}
& \mathrm{e}<0.4=\text { Keseragaman kecil; } \\
& 0,4<\mathrm{e}<0.6=\text { Keseragaman }
\end{aligned}
$$
sedang;

$$
\text { e }>0,6=\text { Keseragaman besar }
$$

(Suryanti dkk, 2014 dalam Septian, Azizah dan Apriadi, 2016):

Indeks Dominansi

Rumus indeks dominansi Simpson, 1949; Odum, 1996 dalam Septian, Azizah dan Apriadi, 2016) dihitung dengan rumus:

$$
\mathrm{C}=\Sigma(\mathrm{ni} / \mathrm{N})^{2}
$$

Keterangan

$$
\begin{array}{ll}
\mathrm{C} & =\text { Indeks dominansi } \\
\mathrm{Ni} & =\text { Jumlah individu spesies-i } \\
\mathrm{N} & =\text { Jumlah individu seluruh }
\end{array}
$$

spesies

Kategori indeks dominansi lamun dibagi atas 3, yaitu: $0,00<C \leq 0,50$ termasuk kedalam kategori rendah; $0,50<\mathrm{C} \leq 0,75$ termasuk kedalam kategori sedang, nilai indeks dominansi $0,75<\mathrm{C} \leq 1,00$ termasuk kedalam kategori tinggi (Setyobudiandy, 2009 dalam Harpiansyah dkk., 2014).

\section{HASIL DAN PEMBAHASAN}

\section{Jenis Lamun di Semenanjung Tarabitan}

Jenis-jenis lamun yang ditemukan di perairan Desa Tarabitan Kecamatan Likupang Barat Kabupaten Minahasa Utara, terdiri dari 6 spesies yang tersebar pada tiga stasiun pengamatan yaitu;

Tabel 5. Keberadaan Jenis Lamun Pada Tiap Stasiun Pengamatan

\begin{tabular}{|c|l|c|c|c|}
\hline No & \multicolumn{1}{|c|}{ Jenis } & $\begin{array}{c}\text { Stasiun } \\
\mathbf{1}\end{array}$ & $\begin{array}{c}\text { Stasiun } \\
\mathbf{2}\end{array}$ & $\begin{array}{c}\text { Stasiun } \\
\mathbf{3}\end{array}$ \\
\hline 1. & $\begin{array}{l}\text { Enhalus } \\
\text { acoroides }\end{array}$ & $*$ & $*$ & $*$ \\
\hline 2. & $\begin{array}{l}\text { Thalassia } \\
\text { hemprichii }\end{array}$ & $*$ & $*$ & $*$ \\
\hline 3. & $\begin{array}{l}\text { Cymodocea } \\
\text { rotundata }\end{array}$ & $*$ & $*$ & $*$ \\
\hline 4. & $\begin{array}{l}\text { Syringodium } \\
\text { isoetifolium }\end{array}$ & $*$ & $*$ & $*$ \\
\hline 5. & $\begin{array}{l}\text { Halophila } \\
\text { ovalis }\end{array}$ & - & $*$ & $*$ \\
\hline 6. & $\begin{array}{l}\text { Halodule } \\
\text { uninervis }\end{array}$ & $*$ & - & $*$ \\
\hline
\end{tabular}

Keteranga : ${ }^{*}=$ ada; - = tidak ada

\section{Kondisi Lamun di Perairan Semenanjung Tarabitan \\ Kerapatan Jenis dan Kerapatan Relatif}

Hasil perhitungan kerapatan jenis dan kerapatan relatif jenis lamun di Semenanjung Tarabitan dapat dilihat pada (Tabel 6) berikut ini: 
Tabel 6. Kerapatan Jenis dan Kerapatan Relatif Lamun di Perairan Semenanjung Tarabitan

\begin{tabular}{|c|c|c|c|}
\hline Spesies & $\begin{array}{c}\text { Jumlah } \\
\text { (Tegakan) }\end{array}$ & $\begin{array}{c}\mathbf{K j i} \\
\text { Tegakan/m² }\end{array}$ & $\mathbf{K R}$ \\
\hline $\begin{array}{c}\text { Enhalus } \\
\text { acoroides }\end{array}$ & 1158 & 23.16 & 20.45 \\
\hline $\begin{array}{c}\text { Thalassia } \\
\text { hemprichii }\end{array}$ & 3145 & 62.90 & 55.55 \\
\hline $\begin{array}{c}\text { Cymodocea } \\
\text { rotundata }\end{array}$ & 418 & 8.36 & 7.38 \\
\hline $\begin{array}{c}\text { Syringodium } \\
\text { isoetifolium }\end{array}$ & 416 & 8.32 & 7.35 \\
\hline $\begin{array}{c}\text { Halophila } \\
\text { ovalis }\end{array}$ & 130 & 2.60 & 2.30 \\
\hline $\begin{array}{c}\text { Halodule } \\
\text { uninervis }\end{array}$ & 395 & 7.90 & 6.98 \\
\hline Total & $\mathbf{5 6 6 2}$ & $\mathbf{1 1 3 . 2 4}$ & $\mathbf{1 0 0}$ \\
\hline
\end{tabular}

Berdasarkan Tabel di atas dapat diketahui bahwa jenis lamun yang memiliki jumlah tegakan paling tinggi yaitu lamun jenis Thalassia hemprichii dengan jumlah tegakan yaitu 3145 tegakan selanjutnya disusul oleh lamun jenis Enhalus acoroides dengan jumlah tegakan yaitu 1158 tegakan, kemudian diikutu oleh lamun jenis Cymodocea rotundata dengan jumlah tegakan yaitu 418 tegakan, selanjutnya diikuti oleh lamun jenis Syringodium isoetifolium dengan jumlah tegakan yaitu 416 tegakan, kemudian diikuti oleh lamun jenis Halodule uninervis dengan jumlah tegakan yaitu 395 tegakan dan jenis lamun yang memiliki jumlah tegakan paling rendah yaitu lamun jenis Halophila ovalis dengan jumlah tegakan yaitu 130 tegakan.

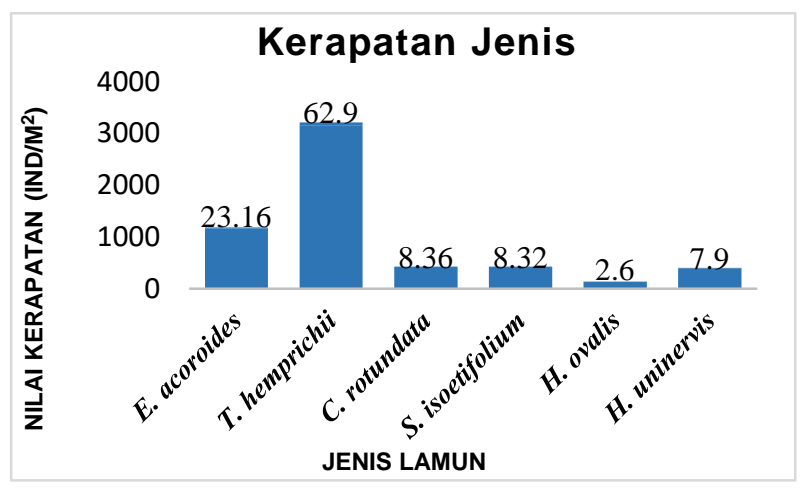

Gambar 4. Nilai Kerapatan Jenis

Kondisi kerapatan lamun pada Perairan Semenanjung Tarabitan tergolong pada skala 3 dengan nilai kerapatan 75 - 125 ind $/ \mathrm{m}^{2}$ yang mengindikasikan bahwa lamun di Semenanjung Tarabitan termasuk lamun dengan kondisi agak rapat, skala kerapatan ini menjadi rujukan untuk menentukan kondisi padang lamun.

Berdasarkan dari hasil perhitungan nilai kerapatan jenis yang telah dilakukan, maka data yang diperoleh lamun dengan jenis $T$. hemprichii memiliki kerapatan paling tinggi jika dibandingkan dengan jenis lamun lainnya yaitu dengan nilai kerapatan 62.90 kerapatan $/ \mathrm{m}^{2}$, E. acoroides dengan nilai kerapatan 23.16 kerapatan $/ \mathrm{m}^{2}$, C. rotundata dengan nilai kerapatan 8.36 kerapatan $/ \mathrm{m}^{2}, S$. isoetifolium dengan nilai kerapatan 8.32 kerapatan $/ \mathrm{m}^{2}, \quad H$. uninervis dengan nilai kerapatan 7.90 kerapatan $/ \mathrm{m}^{2}$, sedangkan lamun jenis $H$. ovalis merupakan lamun dengan nilai kerapatan paling rendah dibandingkan dengan jenis lainnya yaitu dengan nilai kerapatan 2.60 kerapatan $/ \mathrm{m}^{2}$. Tingkat kerapatan jenis lamun tertinggi dimiliki oleh jenis $T$. hemprichii dengan nilai kerapatan 62.90 kerapatan $/ \mathrm{m}^{2}$. Berdasarkan skala kerapatan menurut (Haris dan Gosari, 2012 dalam Martha, Julyantoro dan Sari 2018), lamun jenis $T$. hemprichii dengan nilai di atas tegolong dalam skala 2 dengan tingkat kerapatan berkisar antara $25-75 \mathrm{ind} / \mathrm{m}^{2}$ yang termasuk dalam kondisi kerapatan jarang. Kerapatan lamun yang paling rendah dimiliki oleh lamun jenis $H$. ovalis dengan tingkat kerapatan yaitu 2.60 kerapatan $/ \mathrm{m}^{2}$ olehnya jenis ini tergolong dalam skala 1 dengan kisaran skala yaitu $<25$ yang termasuk lamun dengan kondisi kerapatan sangat jarang.

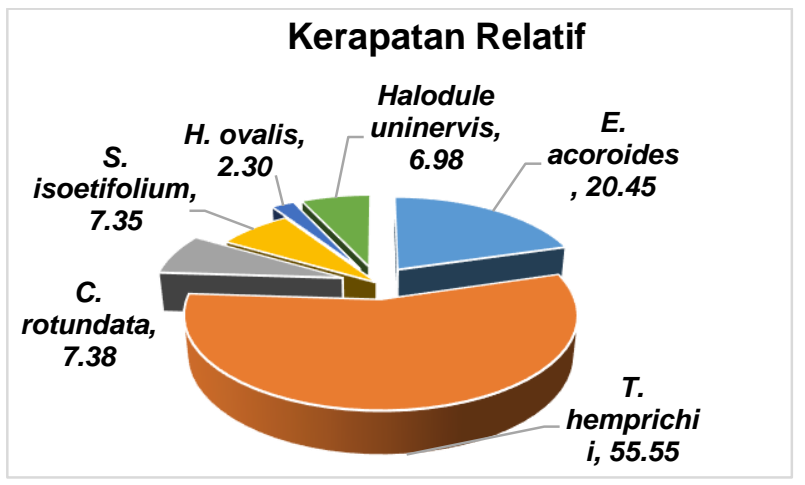

Gambar 5. Nilai Kerapatan Relatif

Melalui hasil perhitungan kerapatan relatif, diketahui lamun yang memiliki nilai 
kerapatan relatif paling tinggi yaitu lamun jenis $T$. hemprichii dengan nilai persentase kerapatan $55.55 \%$ dari jumlah keseluruhan jenis lamun yang ditemukan di perairan Semenanjung Tarabitan. Sedangkan lamun dengan persentase kerapatan relatif paling rendah dimiliki oleh lamun jenis $H$. ovalis dengan persentase kerapatan relatif $2.30 \%$ dari jumlah keseluruhan jenis lamun yang ditemukan.

\section{Frekuensi Jenis dan Frekuensi Relatif}

Hasil dari perhitungan frekuensi jenis dan frekuensi relatif lamun di Perairan Semenanjung Tarabitan dapat dilihat melalui (Tabel 7) berikut ini.

Tabel 7. Frekuensi Jenis dan Frekuensi Relatif

\begin{tabular}{|c|c|c|c|}
\hline Spesies & $\begin{array}{c}\text { Plot } \\
\text { Dijumpai }\end{array}$ & $\begin{array}{c}\text { Frekuensi } \\
\text { Jenis } \\
\text { (FJi) }\end{array}$ & $\begin{array}{l}\text { Frekuensi } \\
\text { Relatif } \\
\text { (FR) }\end{array}$ \\
\hline $\begin{array}{l}\text { Enhalus } \\
\text { acoroides }\end{array}$ & 99 & 1.00 & 33.67 \\
\hline $\begin{array}{l}\text { Thalassia } \\
\text { hemprichii }\end{array}$ & 99 & 1.00 & 33.67 \\
\hline $\begin{array}{l}\text { Cymodocea } \\
\text { rotundata }\end{array}$ & 37 & 0.37 & 12.59 \\
\hline $\begin{array}{l}\text { Syringodium } \\
\text { isoetifolium }\end{array}$ & 21 & 0.21 & 7.14 \\
\hline $\begin{array}{l}\text { Halophila } \\
\text { ovalis }\end{array}$ & 15 & 0.15 & 5.10 \\
\hline $\begin{array}{l}\text { Halodule } \\
\text { uninervis }\end{array}$ & 23 & 0.23 & 7.82 \\
\hline Total & 293 & 2.95 & 100 \\
\hline
\end{tabular}

Melalui hasil pengamatan frekuensi peluang untuk ditemukannya jenis lamun $E$. acoroides dan $T$. hemprichii memiliki nilai frekuensi yang sama yaitu 1.00, dari hal tersebut disimpulkan bahwa lamun jenis $E$. acoroides dan T. hemprichii ditemukan pada keseluruhan plot pengamatan yang berjumlah 99 plot, kemudian disusul lamun jenis $C$. rotundata dengan nilai frekuensi 0.37 yang ditemukan pada 37 plot, jenis $S$. isoetifolium dengan nilai frekuensi 0.21 ditemukan pada 21 plot, jenis $H$. ovalis dengan nilai frekuensi 0.15 ditemukan pada 15 plot dan jenis $H$. uninervis dengan nilai frekuensi 0.23 yang dapat ditemukan pada 23 plot pengamatan. Peluang untuk ditemukannya beberapa jenis lamun tergantung pada jenis subtrat dasar perairan, dikarenakan setiap jenis lamun memiliki tipe substrat yang berbeda untuk menancapkan akarnya (Izuan, 2014 dalam Septian, Azizah dan Apriadi, 2016).

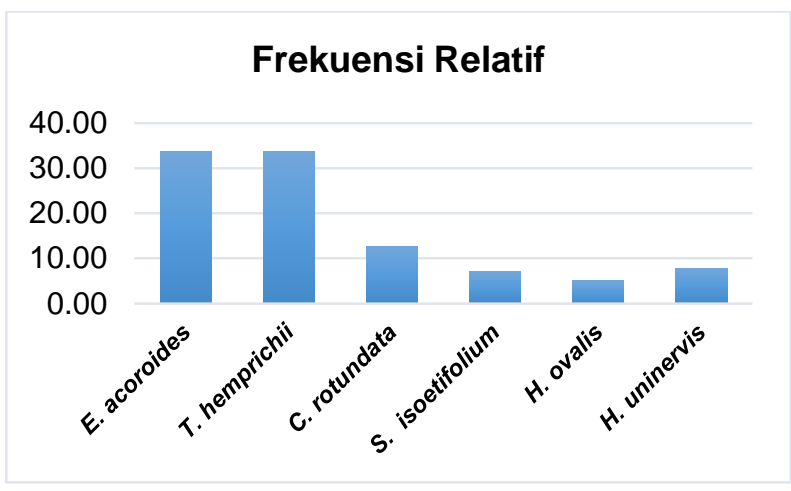

Gambar 6. Frekuensi Jenis

Berdasarkan hasil perhitungan nilai frekuensi relatif jenis lamun yang terdapat di perairan Semenanjung Tarabitan, diketahui bahwa jenis lamun $E$. acoroides dan $T$. hemprichii memiliki nilai persentase frekuensi relatif tertinggi dibanding jenis lamun lainnya yaitu, $33.67 \%$ selanjutnya diikuti oleh lamun jenis $C$. rotundata dengan nilai persentase frekuensi relatif $12.59 \%$, S. isoetifolium dengan nilai persentase frekuensi relatif $7.4 \%, \mathrm{H}$. ovali dengan nilai persentase frekuensi relatif $5.10 \%$ dan $\mathrm{H}$. uninervis yaitu dengan nilai persentase frekuensi relatif yaitu $7.82 \%$.

\section{Frekuensi Jenis}

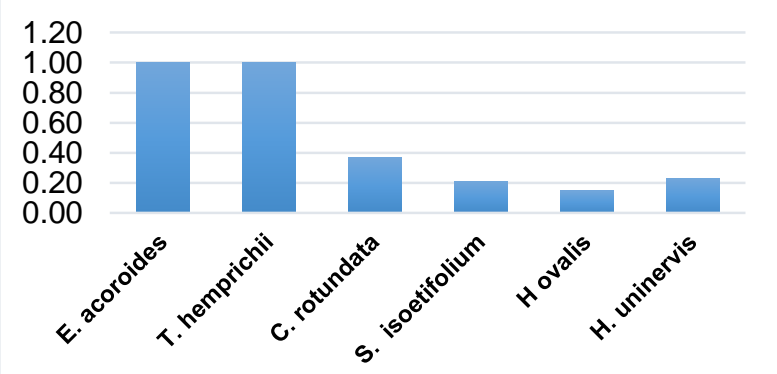

Gambar 7. Nilai Frekuensi Relatif

Melalui hasil perhitungan nilai persentase frekuensi relatif, dapat disimpulkan bahwa lamun jenis $E$. acoroides dan $T$. hemprichii terdapat pada keseluruhan titik pengamatan, hal tersebut mengambarkan bahwa lamun jenis ini memiliki sebaran yang cukup luas serta peluang kehadiran terbesar dibanding dengan lamun jenis lainnya yang terdapat di perairan Semenanjung Tarabitan, sedangkan jenis lamun yang memiliki nilai persentase frekuensi relatif paling rendah yaitu jenis $H$. ovalis yang hanya terdapat pada 
beberapa titik pengamatan, serta keberadaannya tidak merata.

\section{Penutupan Jenis dan Penutupan Relatif}

Hasil dari perhitungan penutupan jenis dan penutupan relatif lamun di Perairan Semenanjung Tarabitan dapat dilihat pada (Tabel 8) berikut ini.

Tabel 8. Penutupan Jenis dan Penutupan Relaif

\begin{tabular}{|l|c|c|}
\hline \multicolumn{1}{|c|}{ Spesies } & $\begin{array}{c}\text { Penutupan } \\
\text { Jenis } \\
\left(\% / \mathbf{m}^{2}\right)\end{array}$ & $\begin{array}{c}\text { Penutupan } \\
\text { Relatif (\%) }\end{array}$ \\
\hline $\begin{array}{l}\text { Enhalus } \\
\text { acoroides }\end{array}$ & 13.44 & 19.00 \\
\hline $\begin{array}{l}\text { Thalassia } \\
\text { hemprichii }\end{array}$ & 28.24 & 39.92 \\
\hline $\begin{array}{l}\text { Cymodocea } \\
\text { rotundata }\end{array}$ & 7.95 & 11.23 \\
\hline $\begin{array}{l}\text { Syringodium } \\
\text { isoetifolium }\end{array}$ & 10.52 & 14.87 \\
\hline Halophila ovalis & 4.47 & 6.31 \\
\hline $\begin{array}{l}\text { Halodule } \\
\text { uninervis }\end{array}$ & 6.13 & 8.66 \\
\hline Total & $\mathbf{7 0 . 7 5}$ & $\mathbf{1 0 0}$ \\
\hline
\end{tabular}

Berdasarkan dari nilai rata-rata penutupan lamun pada Tabel di atas, diketahui bahwa rata-rata penutupan total lamun yang terdapat di Semenanjung Tarabitan yaitu sebesar $70.75 \% / \mathrm{m}^{2}$. Hal tersebut jika ditinjau melalui Kepmen LH No. 200 tahun 2004, tentang penentuan status kesehatan padang lamun, maka berdasarkan ketentuan tersebut, status padang lamun di perairan Semenanjung Tarabitan tergolong pada kondisi kaya/sehat dengan nilai persentase $\geq 60 \%$, hal tersebut merupakan kriteria baku dalam menentukan kesehatan padang lamun yang ditinjau dari luasan tutupan lamun.

Status padang lamun berdasarkan Kepmen LH No. 200 tahun 2004, terdiri dari tiga kategori yaitu, kaya/sehat dengan persentase tutupan $\geq 60 \%$, kurang kaya/kurang sehat dengan persentase tutupan $30-59,9 \%$, dan kategori miskin dengan persentase tutupan $\leq 29,9 \%$.

\section{Penutupan Jenis $\left(\% / \mathrm{m}^{2}\right)$}

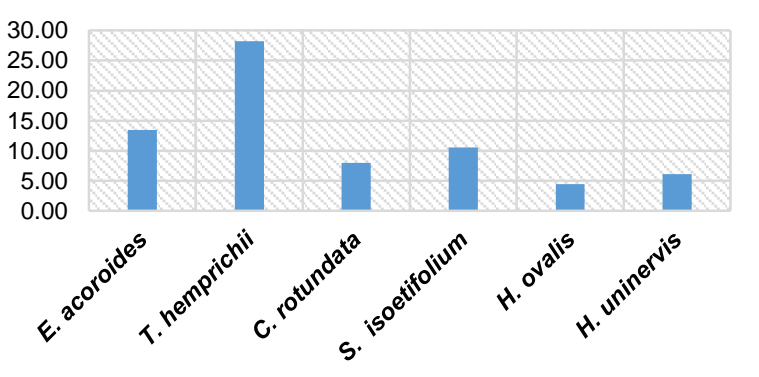

Gambar 8. Nilai Penutupan Jenis

Ditinjau dari hasil perhitungan persentase penutupan jenis lamun yang terdapat di perairan Semenanjung Tarabitan, diketahui bahwa penutupan jenis lamun dengan nilai paling tinggi yaitu, jenis $T$. hemprihii dengan persentase nilai penutupan yaitu $28.24 \% / \mathrm{m}^{2}$, selanjutnya diikuti jenis lamun $E$. acoroides dengan nilai persentase penutupan yaitu $13.44 \% / \mathrm{m}^{2}$, kemudian lamun jenis $S$. isoetifolium dengan nilai persentase penutupan yaitu $10.52 \% / \mathrm{m}^{2}$, berikutnya lamun jenis $C$. rotundata dengan nilai persentase penutupan yaitu $7.94 \% / \mathrm{m}^{2}$, selanjutnya lamun jenis $H$. uninervis dengan nilai persentase penutupan yaitu $6.13 \% / \mathrm{m}^{2}$, sedangkan jenis lamun dengan nilai penutupan paling rendah yaitu, $H$. ovalis dengan nilai persentase penutupan yaitu $4.47 \% / \mathrm{m}^{2}$.

\section{Penutupan Relatif}

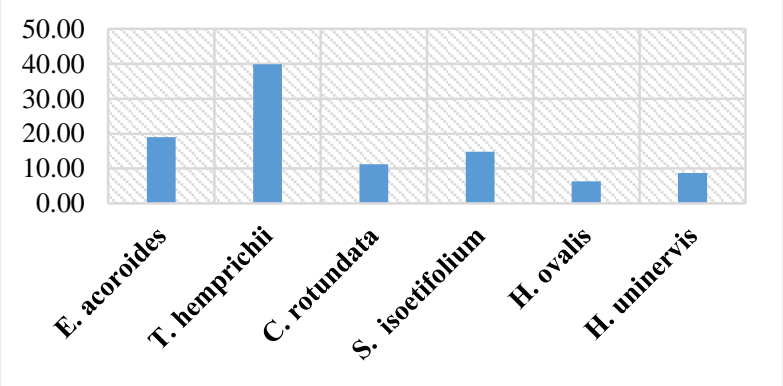

Gambar 9. Nilai Penutupan Relatif

Berdasarkan hasil perhitungan nilai penutupan relatif lamun yang terdapat di perairan Semenanjung Tarabitan, diketahui bahwa lamun jenis $T$. hemprichii memiliki nilai penutupan relatif paling tinggi dibandingkan dengan jenis lainnya, yaitu 39.92\%, selanjutnya diikuti jenis lamun $E$. acoroides 
dengan nilai persentase penutupan relatif yaitu $19.00 \%$, kemudian lamun jenis $S$. isoetifolium dengan nilai persentase penutupan relatif yaitu $14.87 \%$, berikutnya lamun jenis $C$. rotundata dengan nilai persentase penutupan relatif yaitu $11.23 \%$, selanjutnya lamun jenis $H$. uninervis dengan nilai persentase penutupan relatif yaitu $8.66 \%$, sedangkan jenis lamun dengan nilai penutupan relatif paling rendah yaitu, $H$. ovalis dengan nilai persentase penutupan relatif yaitu $6.31 \%$. Hasil penutupan relatif tiap jenis lamun yang terdapat di perairan Semenanjung Tarabitan dapat dilihat pada Gambar berikut ini.

\section{Indeks Nilai Penting}

Hasil dari perhitungan indeks nilai penting lamun yang terdapat di Perairan Semenanjung Tarabitan dapat dilihat pada (Tabel 9) berikut ini.

Tabel 9. Indeks Nilai Penting

\begin{tabular}{|l|c|c|c|c|}
\hline \multicolumn{1}{|c|}{ Spesies } & $\begin{array}{c}\text { KR } \\
(\%)\end{array}$ & $\begin{array}{c}\text { FR } \\
(\%)\end{array}$ & $\begin{array}{c}\text { PR } \\
(\%)\end{array}$ & $\begin{array}{c}\text { INP } \\
(\%)\end{array}$ \\
\hline $\begin{array}{l}\text { Enhalus } \\
\text { acoroides }\end{array}$ & 20.45 & 33.56 & 19.00 & 73.01 \\
\hline $\begin{array}{l}\text { Thalassia } \\
\text { hemprichii }\end{array}$ & 55.55 & 33.56 & 39.92 & 129.03 \\
\hline $\begin{array}{l}\text { Cymodocea } \\
\text { rotundata }\end{array}$ & 7.38 & 12.67 & 11.23 & 31.28 \\
\hline $\begin{array}{l}\text { Syringodium } \\
\text { isoetifolium }\end{array}$ & 7.35 & 7.19 & 14.87 & 29.41 \\
\hline $\begin{array}{l}\text { Halophila } \\
\text { ovalis }\end{array}$ & 2.3 & 5.14 & 6.31 & 13.75 \\
\hline $\begin{array}{l}\text { Halodule } \\
\text { uninervis }\end{array}$ & 6.98 & 7.88 & 8.66 & 23.52 \\
\hline Total & $\mathbf{1 0 0}$ & $\mathbf{1 0 0}$ & $\mathbf{1 0 0}$ & $\mathbf{3 0 0}$ \\
\hline
\end{tabular}

Berdasarkan hasil perhitungan INP pada Tabel di atas diketahui bahwa INP dari jenis lamun T. hemprichii yaitu $129.03 \%$ yang merupakan jenis lamun dengan nilai INP paling besar. Selanjutnya diikuti oleh lamun jenis $E$. acoroides dengan INP yaitu, 73.01\%, kemudian lamun jenis $C$. rotundata dengan INP yaitu, $31.28 \%$, kemudian lamun jenis $S$. isoetifolium dengan INP yaitu, 29.41\%, berikutnya lamun jenis $H$. uninervis dengan INP yaitu, $23.52 \%$, dan yang terakhir yaitu lamun jenis $H$. ovalis dengan INP yaitu, $13.75 \%$, lamun jenis ini merupakan lamun dengan nilai INP paling rendah dari keseluruhan jenis yang ditemukan.

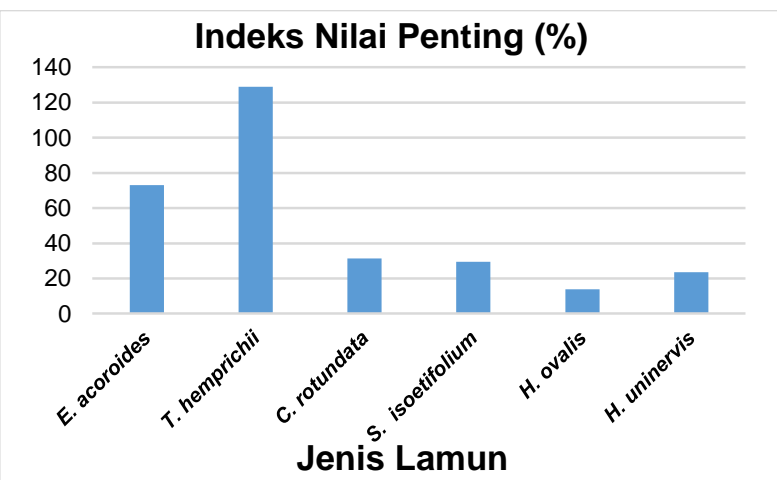

Gambar 10. Indeks Nilai Penting

INP digunakan untuk menghitung serta menduga keseluruhan dari peranan jenis lamun di dalam sutu komunitas. Semakin besar nilai INP suatu jenis relatif terhadap jenis yang lain, maka hal ini mengindikasikan bahwa semakin besar juga pengaruh suatu jenis lamun pada komunitas tersebut (Suhud, Pratomo dan Yandri, 2012).

Ditinjau dari hasil perhitungan INP pada Tabel 9 dikatakan bahwa lamun dengan INP paling besar dimiliki oleh lamun jenis $T$. Hemprichii yaitu, $129.03 \%$ hal ini mengindikasikan bahwa lamun jenis $T$. hemprichii memiliki pengaruh paling besar pada ekosistem padang lamun yang berada di perairan tersebut. Hal tersebut diduga disebabkan oleh tigal unsur yang berperan pada besar dan kecilnya nilai INP yaitu nilai frekuensi relatif, kerapatan relatif dan tutupan relatif (Suhud, Pratomo dan Yandri, 2012).

\section{Indeks Keanekaragaman, Keseragaman dan Dominansi}

Hasil dari perhitungan indeks keanekaragaman, keseragaman serta dominasi lamun yang terdapat di Perairan Semenanjung Tarabitan dapat dilihat pada (Tabel 10) berikut ini.

Tabel 10. Indeks Keanekaragaman, Keseragaman dan Dominasi

\begin{tabular}{|c|l|c|l|}
\hline No & \multicolumn{1}{|c|}{ Indeks } & Nilai & \multicolumn{1}{|c|}{ Kondisi } \\
\hline 1 & Keanekaragaman & 1.30 & Sedang \\
\hline 2 & Keseragaman & 0.72 & Tinggi \\
\hline 3 & Dominansi & 0.2 & Rendah \\
\hline
\end{tabular}


Berdasarkan hasil perhitungan indeks keanekaragaman dari ekosistem padang lamun pada perairan Semenanjung tarabitan yaitu, $\quad 1.30$ yang termasuk pada pengkategorian keanekaragaman sedang yaitu $1<H^{\prime}<3$. Keanekaragaman akan memiliki nilai tinggi jika seluruh individu berasal dari jenis yang berbeda-beda, sebaliknya nilai paling kecil didapatkan jika individu yang ditemukan berasal dari jenis yang sama (Odum, 1996 dalam Septian, Azizah dan Apriadi, 2016). Keanekaragaman sedang pada ekosistem padang lamun di perairan Semenanjung Tarabitan, disebabkan oleh jenis lamun yang ditemukan hanya berjumlah 6 jenis. Hal tersebut mempengaruhi tinggi serta rendahnya nilai indeks keanekaragaman jenis lamun dapat berasal dari berbagai faktor diantaranya yaitu, jumlah dari jenis lamun yang ditemukan terdiri dari beberapa jenis yang melimpah dibandingkan dengan jenis lainnya, tipe substrat yang homogen, kondisi dari ekosistem lamun yang juga menjadi ekosistem beragam fauna perairan (Yanu, 2011 dan Suryanti dkk, 2014, dalam Septian, Azizah dan Apriadi, 2016).

Hasil dari perhitungan nilai indeks keseragaman lamun yang ditemukan pada perairan Semenanjung Tarabitan yaitu 0.72 yang tergolong dalam kategori keseragaman besar yaitu, e > 0,6. Tingginya nilai keseragaman mengindikasikan bahwa tidak ada jenis lamun yang mendominasi serta perbedaan jumlah jenis lamun yang tidak terlalu tinggi. Jika indeks keseragaman kecil maka semakin besar perbedaan jumlah jenis lamun hal tersebut mengindikasikan adanya jenis lamun yang mendominasi (Tishmawati, 2014 dalam Marta, Julyantoro, dan Sari, 2017).

Tingginya nilai indeks keseragaman mengidikasikan bahwa adanya keseimbangan yang tinggi di dalam komposisi individu pada setiap jenis penyusunnya (Marta, Julyantoro, dan Sari, 2017). Hal tersebut sejalan dengan nilai indeks dominansi yang tergolong dalam kategori rendah yaitu, dengan nilai 0.2. Rendahnya nilai dominansi mengindikasikan bahwa kondisi ekosistem padang lamun yang berada di Semenanjung Tarabitan masih stabil sehingga tidak menyebabkan tekanan ekologis terhadap biota yang berasosiasi di perairan
Semenanjung Tarabitan serta tidak ada jenis lamun yang mendominasi.

\section{KESIMPULAN}

Jenis-jenis lamun yang teridentifikasi di lokasi penelitian, yaitu: Enhalus acoroides, Thalassia hemprichii, Cymodocea rotundata, Syringodium isotifolium, Halophila ovalis dan Halodule uninervis, dengan Indeks Keanekaragaman Sedang; Indeks Keseragaman tinggi; dan Indeks Dominansi Rendah. Berdasarkan Keputusan Menteri Lingkungan Hidup Nomor 200 Tahun 2004, kondisi padang lamun di perairan Desa Tarabitan tergolong kaya / sehat dengan nilai tutupan $\geq 60$.

\section{DAFTAR PUSTAKA}

Azkab H. M. 2000. Struktur dan Fungsi Pada Komunitas Lamun. Sumber: www.oseanografi.lipi.go.id. Jurnal Oseana. 25 (3): 9-17.

Dahuri R. 2003. Keanekaragaman hayati laut, asset pembangunan berkelanjutan Indonesia, Penerbit PT. Gramedia Pustaka Utama. Jakarta. 412 hal.

Hartini H. dan Y. Lestarini. 2019. Pemetaan Padang Lamun Sebagai Penunjang Ekowisata di Kabupaten Lombok Timur. Jurnal Biologi Tropis. 19 (1): 17.

Kusumaningtyas A. M., A. Rustam., T. L. Kepel., R. N. A. Ati., A. Daulat., P. Mangindaan \& A. A. Hutahaean. 2015. Ekologi dan Struktur Komunitas Lamun Di Teluk Ratatotok, Minahasa Tenggara, Sulawesi Utara. Jurnal Segara. Pusat Penelitian Dan Pengembangan Sumber Daya Laut Dan Pesisir, Balitbang-KP, KKP. 12 (1): 1-9.

McKenzie L. J. 2003. Guidelines for The Rapid Assessment And Mapping of Tropical Seagrass Habitat. Seagrass Watch $H Q$. 24 hal.

McKenzie L. J., S. J. Campbell \& C. A. Roder. 2003. Seagrass-Watch: Manual for Mapping \& Monitoring Seagrass Resources. $2^{\mathrm{EN}}$ Edition. Departement of 
Primary Industries Queensland, Northem Fisheries Center. 46 hal.

Martha L. G. M. R., G. S. P. Julyantoro \& H. W. A. Sari. 2018. Kondisi dan Keanekaragaman Jenis Lamun di Perairan Pulau Serang, Provinsi Bali. Jurnal of Marine Aquatik Science. 5 (1): 131-141.

Rahmawati S., A. Irawan., I. H. Supryadi \& M. H. Azkab. 2014. Panduan Monitoring Padang Lamun. COREMAP CTI LIPI Jakarta. 50 hal.

Rahmawati S. 2011. Ancaman Terhadap Komunitas Padang Lamun. Jurnal Oseana. 36 (2): 49-58.

Supriharyono. 2009. Konservasi Ekosistem Sumberdaya Hayati Di Wilayah Pesisir Dan Laut Tropis. Pustaka Pelajar; Yogyakarta. 514 hal.

Sakaruddin M. I. 2011. Komposisi Jenis, Kerapatan, Persen Penutupan dan Luas Penutupan Lamun di Perairan Pulau Panjang. 71 hal.

Sitorus A. R. S. S. 2011. Kajian Sumberdaya Lamun Untuk Pengembangan Ekowisata di Desa Teluk Bakau, Kepulauan Riau. Departemen Manajemen Sumberdaya Perairan, Fakultas Perikanan dan Ilmu Kelautan, Institut Pertanian Bogor. 115 hal.

Sjafrie N. D. M., U. E. Hermawan., B. Prayudha., M. Y. Iswari., Rahmat., K. Anggraini., R. Rahmawati., Suyarso \& I. H. Supriyadi. 2018. Status Padang Lamun Indonesia. Pusat Penelitian Oseanografi - Lembaga IImu Pengetahuan Indonesia LIPI. Ver. 02. 50 hal.

Septian A. E., D. Azizah., \& T. Apriadi. 2016. Tingkat Kerapatan Dan Penutupan Lamun Di Perairan Desa Sebong Pereh Kabupaten Bintan. Jurnal Manajemen Sumberdaya Perairan, Fakultas IImu Kelautan Dan Perikanan Universitas Maritim Raja Ali Haji Tanjung Pinang. 15 hal.
Syukri A., Y. Wadiatno., I. Muchin \& M. M. Kamal. 2017. Kerusakan Lamun (Seagrass) dan Rumusan Konservasinya di Tanjung Luar Lombok Timur. Jurnal IImiah Program Studi Pendidikan Biologi Universitas Mataram, Departemen Manajemen Sumberdaya Perairan, Fakultas Perikanan dan IImu Kelautan Institut Pertanian Bogor. Jurnal Biologi Tropis. 17 (2): 69-80.

Syukri A. 2016. Konservasi Lamun Untuk Keberlanjutan Sumberdaya Ikan di Perairan Pesisir Indonesia. Jurnal Biologi Tropis. 16 (1): 56-68.

Suhud M. A., A. Pratomo., \& F. Yandri. 2012. Struktur Komunitas Lamun di Perairan Pulau Nikoi. Jurnal Ilmiah Universitas Maritim Raja Ali Haji. 9 hal.

Tangke U. 2010. Ekosistem Padang Lamun (Manfaat, Fungsi dan Rehabilitas). Jurnal IImiah Agribisnis dan Perikanan. Vol. 3 Edisi 1. 9-29.

Wagey B. 2013. Hilamun (Seagrass). Unsrat Press. 124 hal.

Wirawan A. A. 2014. Tingkat Kelangsungan Hidup Lamun Yang Ditransplantasi Secara Multispesies Di Pulau Barranglompo. Jurusan IImu Kelautan dan Perikanan, Universitas Hasanuddin Makassar. $61 \mathrm{Hal}$. 